\title{
CHANGES IN FISHING EFFICIENCY OF THE POLE-AND- LINE SKIPJACK TUNA FLEET BASED AT SORONG, IRIAN JAYA, INDONESIA
}

\author{
Nicholas J.F. Rawlinson", Budi Iskandar PS ${ }^{*+1}$, David A. Milton ${ }^{* * *}$, \\ and Bachtiar Gafa*t)
}

\begin{abstract}
ABSTRAC'T
Data from the fishing operations of the pole-and-line fishing fleet based in Sorong, Irian Jaya, eastern Indonesia are examined to assess the status of the fishery in that region. A General Linear Model was used to derive standardised indices of relative vessel efficiencies for the baitfish used per boat day and tuna caught per boat day.

The most appropriate models in each case were $\mathrm{Ln}$ (Bait used) $=$ Constant + Year + Month + Vessel which explained $56 \%$ of the variation in the bait used per boat day and Ln (Tuna catch $)=$ Constant + Year + Month + Vessel $+\operatorname{Ln}($ Bait/boat day) which explained 53\% of the catch-effort variation for tuna. Parameters for relative vessel efficiencies were used to standardise the recorded fishing effort.

By 1992. fishing effort (boat days) for baitfish and tuna had increased by approximately $800 \%$ since the start of the fishery in 1976 . Relationships between both baitfish used and tuna caught, and standardised fishing effort were linear and tuna catches were strongly dependent on the amount of bait available. The pole-and-line fleet has experienced declining bait usage and tuna catches per boat day since 1992. The reasons for this are unclear from the available data but may be related to changes in the operations of the bagan fishery that supplies baitfish or a decline in the abundance of these fish.
\end{abstract}

KEYWORDS: skipjack tuna, Sorong, baitfish, CPUE.

\section{INTRODUCTION}

The pole-and-line fisheries for skipjack (Katsuwonus pelamis) and yellowfin tuna (Thunnus albacares) are important commercial fisheries in eastern Indonesia (Naamin \& Gafa, this volume). One of the largest fleets of pole-and-line vessels in eastern Indonesia is based at Sorong, Irian Jaya and operates for the state fishing company, $\mathrm{P}^{\prime} \mathrm{T}$ Usaha Mina (Usaha Mina).

The success of pole-and-line fishing is totally reliant on a regular nightly supply of baitfish which are caught in a totally separate fishery. Baitfish are taken at night in inshore areas by baitfishing units, known locally as bagans, or less commonly by the pole-and-line vessels themselves using the "basnig" system (See Naamin \& Gafa, this volume, for a detailed description of the fishing methods, fishing grounds and the species com. position of baitfish).

Owners/operators of the bagans receive payment based on the number of buckets of baitfish that they supply to the pole-and-line vessels. The captain of the pole-and-line vessel records on a logsheet. the number of buckets of baitfish that he receives each night from each bagan. The logsheets are returned to the Usaha Mina office where the number of buckets of baitfish that have been supplied by each bagan is calculated. These data are compiled on a monthly basis.

Usaha Mina uses the same data source to compile details of the number of buckets of baitfish supplied to each pole-and-line vessel per month. In addition to this, the amount of tuna landed and the number of fishing days undertaken by each pole-and-line vessel during each month are recorded.

\section{Purpose of the Study}

The initial aim of this study was to review the historical catch and effort data that had been collected by Usaha Mina in order to assess the baitfish stocks. However, the basic assumption of using catch per unit effort (CPUE) data to monitor the status of a fishery is that changes in CPUE

\footnotetext{
Faculty of Fisheries and Marine Environment, Australian Maritime College, Australia

" Research Institute for Marine Fisheries

"..*, CSIRO Marine Research. Australia
} 
accurately reflect changes in the abundance of fish in the stock (King, 1995).

The data collected by Usaha Mina did not provide measures of catch or effort that would allow us to meet this assumption. The catch estimates were based solely on the amount of baitfish transferred to the pole-and-line vessel. This figure would be an underestimate of the total catch as:

(a) Baitfish are often held in the bagans for 24-48 hours during which time there would be some mortality - some estimates suggest that the mortality rate maybe as high as $30 \%$ of baitfish that are held in the bagan for a day. Usaha Mina only records the live baitfish transferred to the pole-and-line vessels and the fish that die in the bagans would not be included.

(b) Some baitfish are used for human consumption (Naamin \& Gafa, this volume) and not supplied to the pole-and-line vessels. During the season of peak abundance of baitfish the amount of baitfish sold as food can be as high as $50 \%$ of the total catch. The baitfish caught for human consumption is not recorded in the Usaha Mina records and would vary between months.

The number of fishing days is used to estimate fishing effort, but the number of lifts of the bagan net during a night would be a more accurate mea- sure of effective effort. Bagans often make more than one haul of their net per night and therefore operational fishing days would be an underestimate of the true fishing effort.

The data could not be used to calculate a measure of CPUE that could be used as an index of abundance and therefore it was not possible to assess the baitfish stocks using the available information.

\section{Changes in Fleet Structure}

However, the data did allow us to examine the structure of the pole-and-line fleet based at Sorong. The number of pole-and-line vessels operating has increased to 49 in 1995 from an initial fleet size of 19 in 1976. The size composition of the pole-andline fleet operating from Sorong has also changed (Figure 1). The original fleet was comprised of 30 GT vessels but since 1990 there has been the addition of larger vessels.

Kimura (1981) recognised that fishing power generally differs among vessels, and if catch per unit effort is to be proportional to abundance, effort measurements must be standardised. As the size structure of the fishing fleet in Sorong has changed, the relative fishing power is likely to have increased and therefore the units of fishing effort

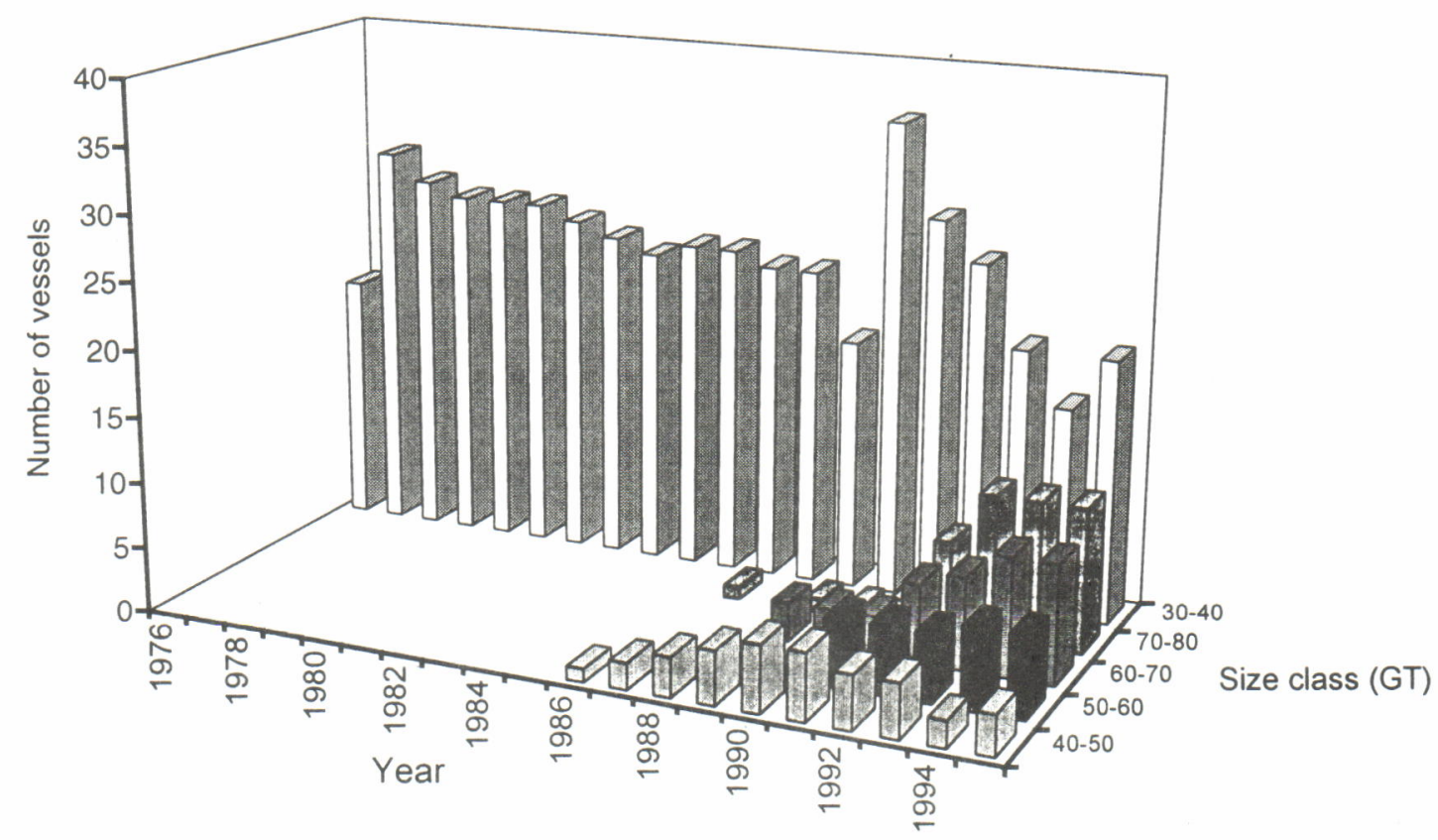

Figure 1. The number of pole-and-line vessels by size class (in gross tonnage) operating from Sorong from 1976 to 1995. 
would need to be standardised over time to obtain a true indication of increases in fishing effort.

The aim of this paper was to use the available data from Sorong to make comparisons between the amount of baitfish used per day by individual pole-and-line vessels and to assess the relative efficiency of pole-and-line vessels in terms of tuna caught per day. These parameters were used to provide a standardised measure of fishing effort for both baitfish and tuna.

\section{METHODS}

\section{Data Collection}

Usaha Mina compiles data for the amount of baitfish used, the amount of tuna landed and the number of fishing days for each pole-and-line vessel on a monthly basis. These data were entered into a Microsoft Access database. Each record in the database contained the name of the vessel operating from Sorong, the month and year of operation of that vessel, and the number of buckets of baitfish used, the amount of tuna landed and the number of fishing days for the that vessel during that particular month. From these data it was possible to generate the amount of baitfish used per fishing day and the amount of tuna caught per fishing day for each vessel for each month.

\section{Data Analysis}

\section{Analysis of catch and effort data}

Annual and monthly summaries of number of buckets of baitfish used, the amount of tuna landed and the number of fishing days were generated using the query routine within Microsoft Access.

\section{Vessel comparisons of bait used per day and tuna catch per day}

The catch rate of vessel at a particular time $\left(U_{t i}\right)$, where subscript $t$ refers to time and $i$ refers to the vessel can be written as a statistical model as follows:

$$
\begin{aligned}
\mathrm{U}_{\mathrm{ti}}= & U_{1 \mathrm{i}} \cdot \mathrm{x}_{1 \mathrm{t}} \mathrm{al}^{\mathrm{a}} \cdot \mathrm{x}_{2 \mathrm{i}}^{\mathrm{a} 2} \ldots \mathrm{x}_{\mathrm{n}}^{\mathrm{an}} \ldots \\
& \rho^{\beta} \mathrm{y}_{1 \mathrm{y}} \cdot \ell^{\beta} 2 \mathrm{y}_{2 \mathrm{t}} \ldots \ell^{\beta} y_{\mathrm{n}} \ldots \ell^{\varepsilon_{\mathrm{ti}}}
\end{aligned}
$$

where $U_{l i}$ is the catch rate obtained by the first vessel class in the first time period, $\mathbf{a}_{1}$ is a factor that is the abundance in year $t$ relative to year 1 , $\dot{\mathrm{a}}_{2}$ is the efficiency of the vessel $i$ relative to vessel 1 , and is a factor that accounts for the deviation between the observed $U_{t i}$ and the expected value for $t$ and $i$.

We can obtain a linearised form of the model:

$$
\begin{aligned}
& \log \left(\mathrm{U}_{\mathrm{ti}}\right)=\log \left(\mathrm{U}_{1 \mathrm{i}}\right)+\alpha_{1} \log \left(\mathrm{x}_{1}\right)+\alpha_{2} \log \left(\mathrm{x}_{2}\right)+\ldots \\
& +\alpha_{11} \log \left(\mathrm{x}_{\mathrm{n}}\right)+\beta_{1} \mathrm{y}_{1}+\beta_{2} \mathrm{y}_{2} \ldots+\beta_{n} \mathrm{y}_{\mathrm{n}}+\varepsilon_{\mathrm{ti}}
\end{aligned}
$$

Variables in the models can either be continuous $\left(x_{1 . .1}\right)$ or categorical (having discrete values: $\left.y_{1 . n}\right)$. Categorical variables can be included in the model by using dummy variables (variables that take only the values of zero or one) (Rawlings $e t$ al., 1998). Variables such as year, month and vessel are all categorical variables.

We can estimate the values of $U_{1 i} \alpha_{1} \alpha_{2} . . \alpha_{n} \beta_{1}$ $\beta_{2,}$ and $\beta_{n}$ using the Generalised Linear Model (GLM) (Hilborn \& Walters 1992) routine in Systat. The raw data for baitfish used per day (Figure 2) and tuna catch per day (Figure 3) exhibited a log. normal distribution and were normalised using a natural log transformation (Figure 4 for baitfish, Figure 5 for tuna) All analyses were run using the GLM routine in Systat (Version 7). The variables Vessel, Year and Month were all put into the analysis as dummy variables.

In order to assess the best fit for combinations of variables in the model, the adjusted coefficient of determination, $r^{2}{ }_{a d j}$ was calculated from:

$$
r^{2} a d j_{j}=1-\frac{\left(1-r^{2}\right)(n-1)}{\left(n-p^{\prime}\right)}
$$

where $n$ is the sample size, $p^{\prime}$ is the number or parameters in the model and $r^{2}$ is the coefficient of determination, which is a measure of the contribution of the independent variable(s) in the model.

The adjusted coefficient of determination, $r^{2}$ removes the impact of degrees of freedom and gives a quantity that is more comparable than $R^{2}$ over models involving different numbers of parameters. The value of $r^{2}{ }_{a d j}$ will tend to stabilise around some upper limit as variables are added. Variables were added to or deleted to obtain the simplest model with $r^{2}{ }_{a d j}$ near this upper limit. These variables were selected to provide the 'best' model (Rawlings et al., 1998). 


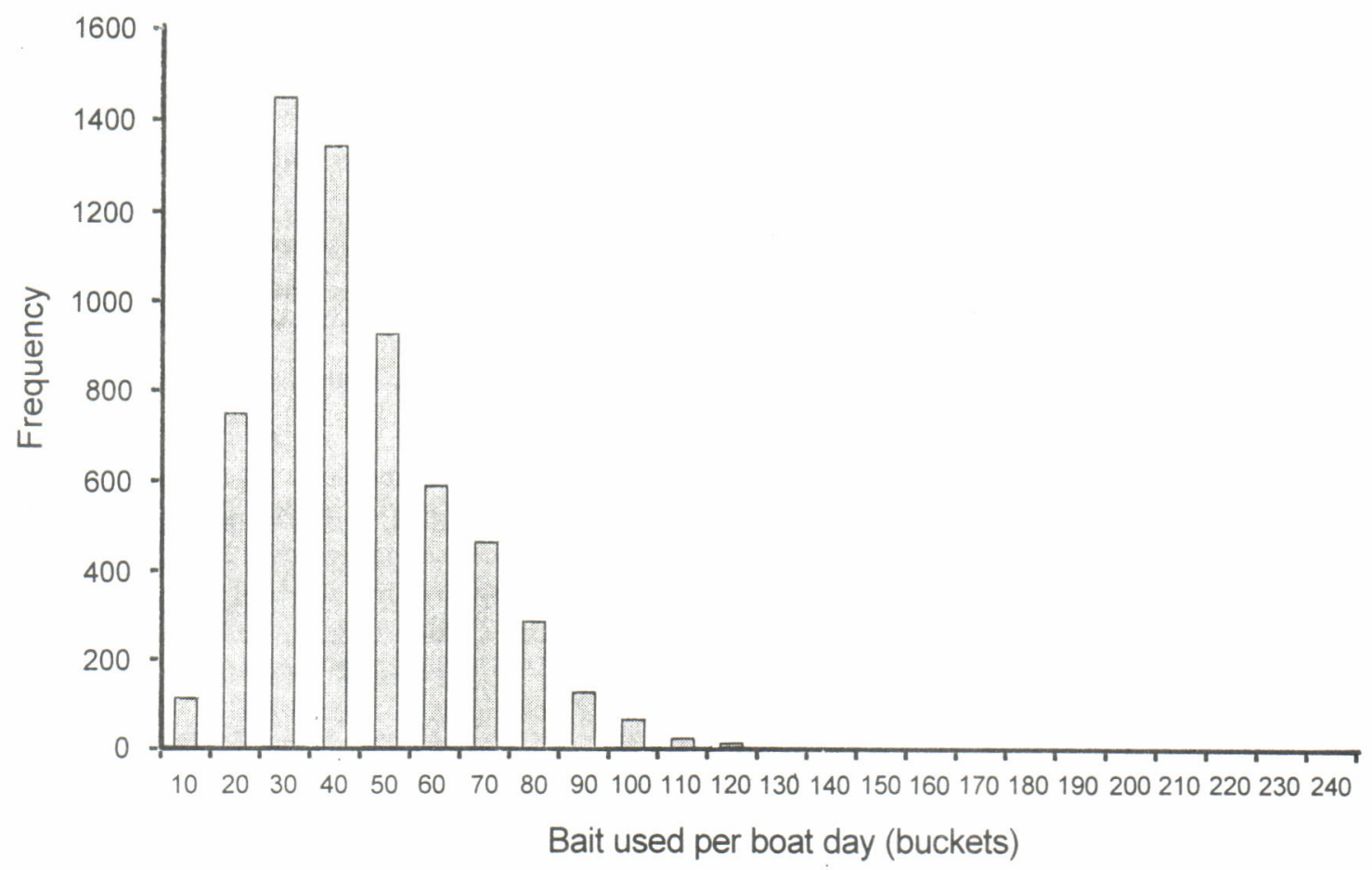

Figure 2. Frequency distribution of monthly values of baitfish used per boat day for each vessel from 1976 to 1995.

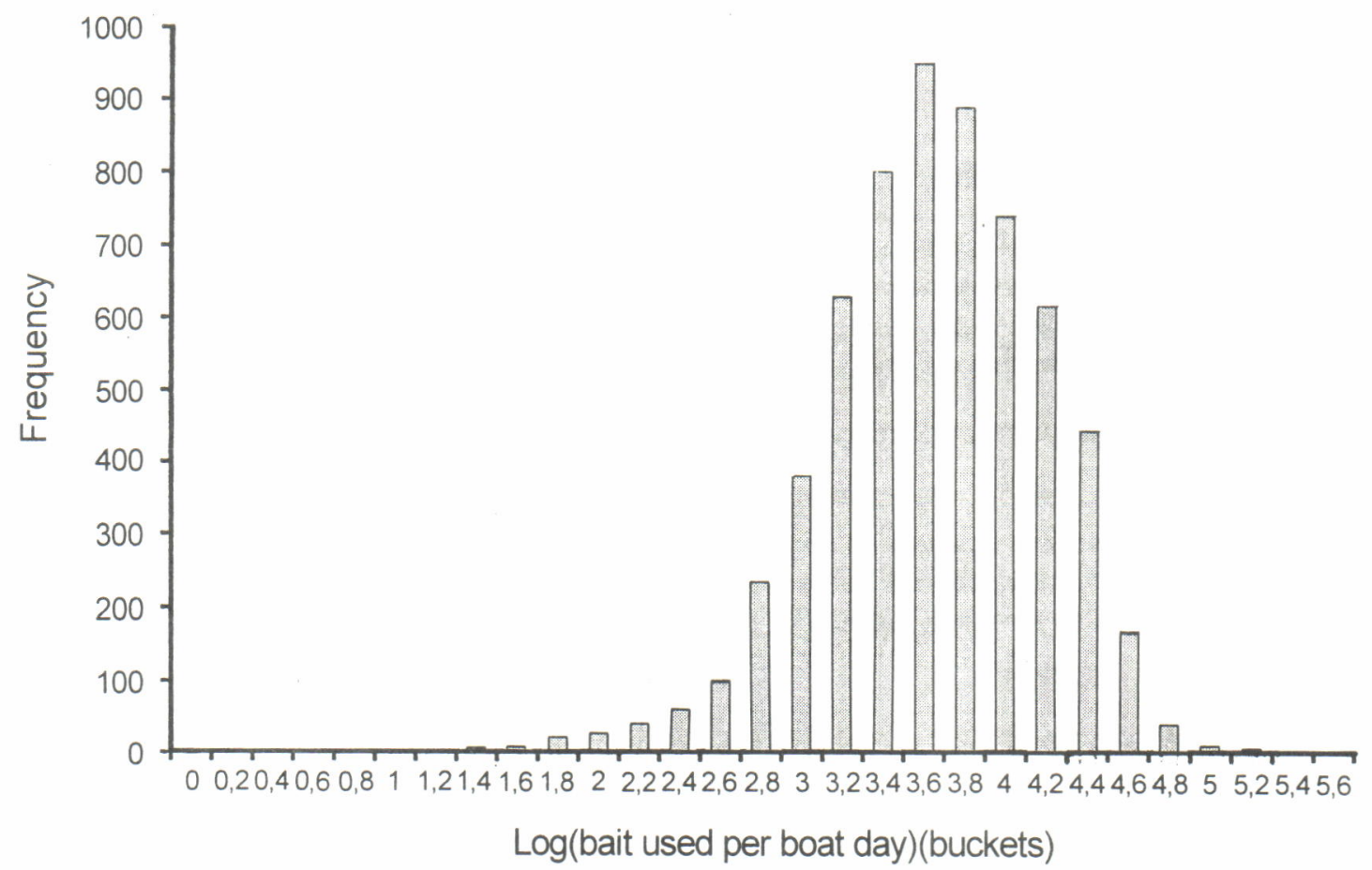

Figure 3. Frequency distribution of monthly values of baitfish used per boat day for each vessel from 1976 to 1995 following natural logarithm transformation. 


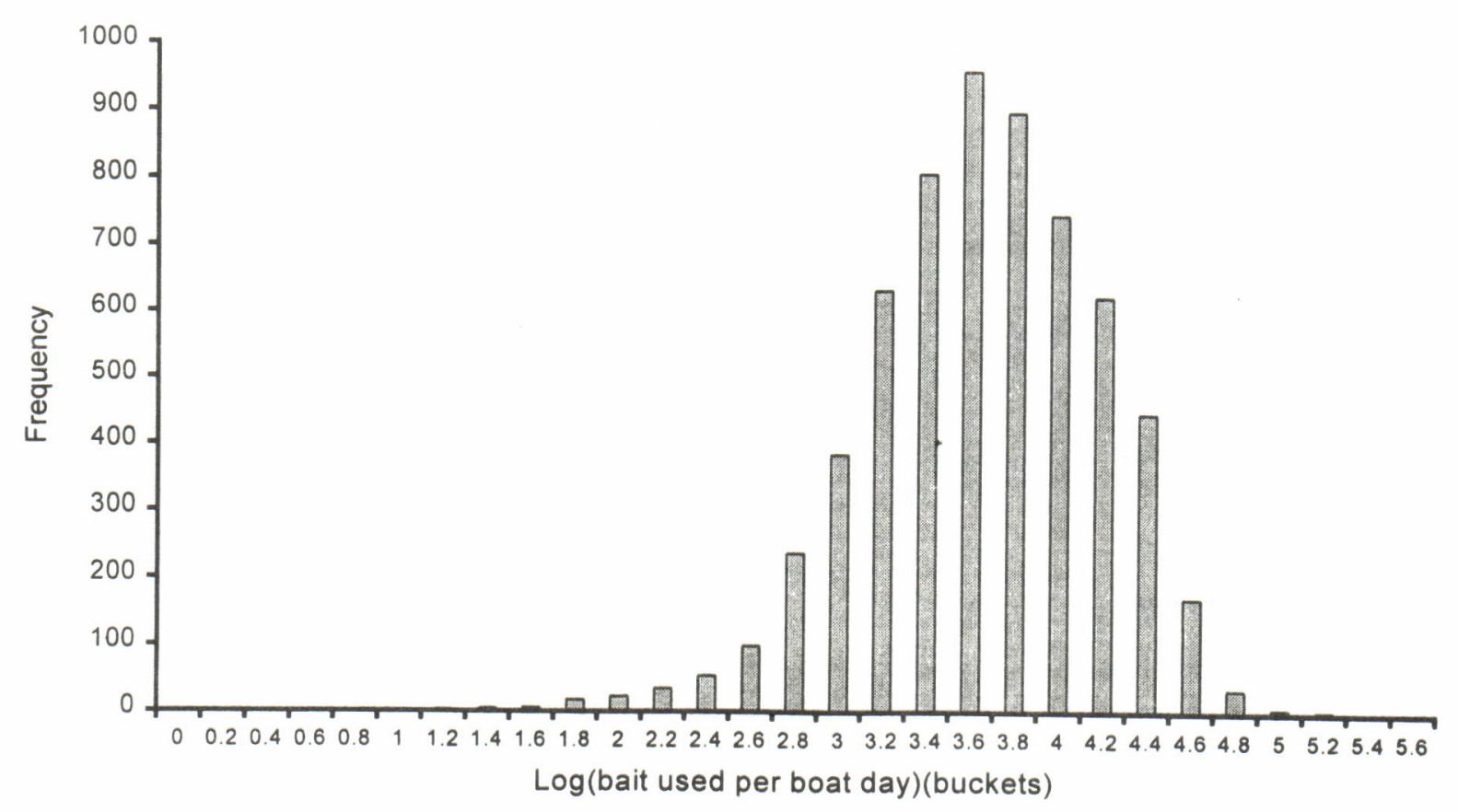

Figure 4. Frequency distribution of monthly values of tuna caught per boat day for each vessel from 1976 to 1995 following natural logarithm transformation.

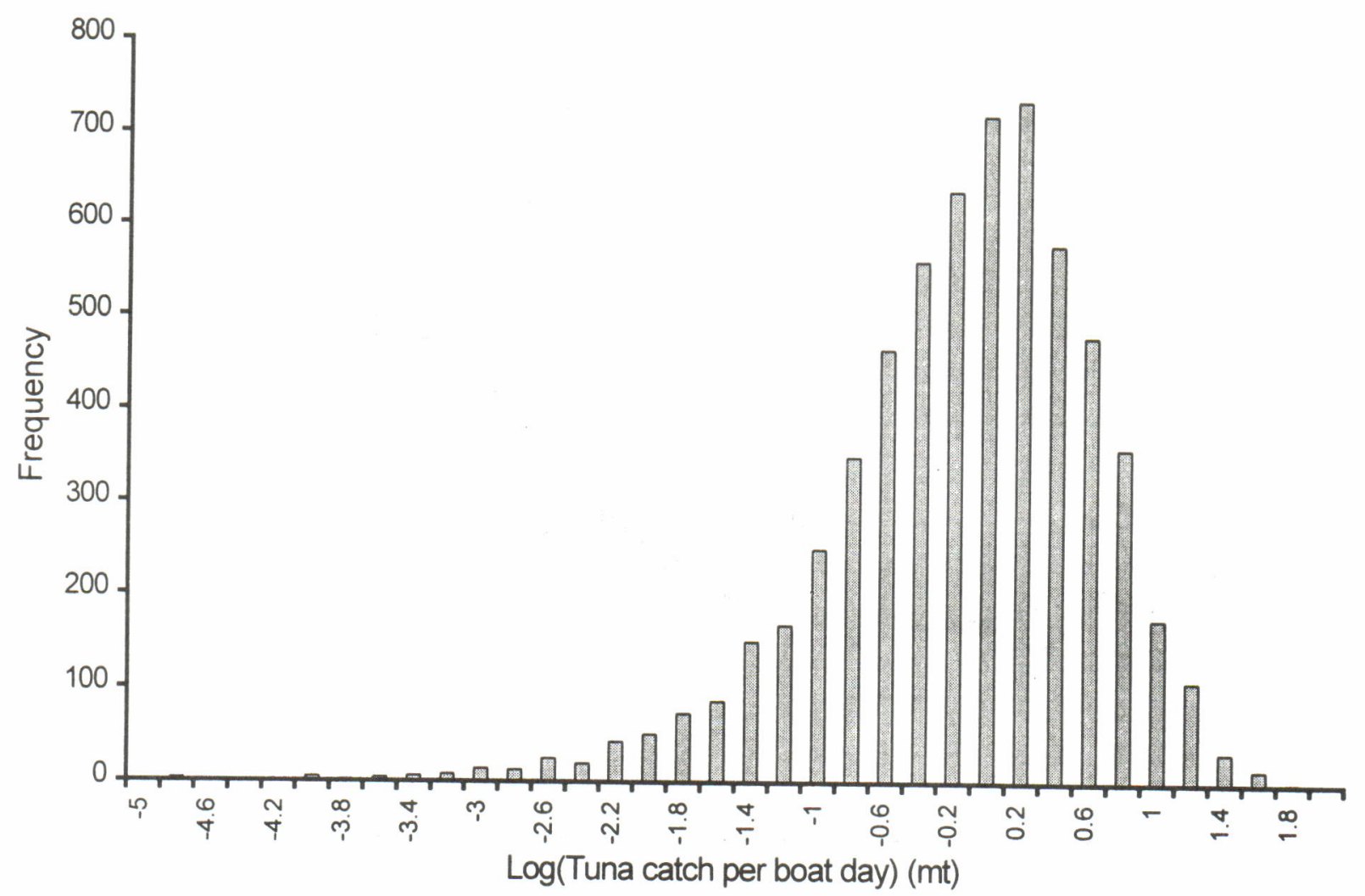

Figure 5. Frequency distribution of monthly values of tuna caught per boat day for each vessel from 1976 to 1995 following natural logarithm transformation. 
The parameters for each pole-and-line vessel were inverse-logarithm transformed to provide a factor that represented the amount of baitfish used per day and the amount of tuna caught per day compared to the performance of one of the original Usaha Mina 30GT pole-and-line vessels oper. ating in September 1976.

The recorded number of fishing days per month for each vessel was multiplied by the factor for the corresponding vessel to obtain a standardised measure of fishing effort.

\section{RESULTS}

\section{Bait Caught per Day}

There were 6154 monthly records of vessels that had complete estimates of both baitfish used and number of fishing days. These data covered the operations of a total of 85 different pole-andline vessels from April 1976 to October 1995. Not all vessels were in operation over this whole period as older vessels were decommissioned and new vessels joined the fleet.

There has been an increase in the amount of baitfish used per boat day from 1976 to 1991 with a decline after 1991 (Figure 6). The increased use of baitfish per vessel can be attributed to the larger size classes of pole-and-line vessels joining the fleet which are able to carry larger amounts of baitfish. However the decline since 1991 must be due to a reduced supply of baitfish as the size composition of the fleet has not decreased during this period.

The total bait used by all vessels plotted against the total (uncorrected) number of operational fish. ing days (nominal fishing effort) shows that there has been an exponential increase in bait used per boat day at the higher levels of fishing effort (Fig. ure 7). This is due to the fact that the higher levels of fishing effort have occurred in the years when the larger size classes of vessel have joined the fleet. The larger vessels have a greater capacity for carrying baitfish, therefore the amount of baitfish used per boat day has increased over time.

\section{Vessel comparisons for bait used per boat day}

The progressive improvement in the quantity of the total variation explained by the models for the amount of bait used per boat day is shown in 'Table 1. The 'best' model including the variables vessel, year and month accounted for about $56 \%$ of the variability in the monthly bait used per vessel $(F=70.3, \mathrm{df}=114, P<0.0001)$. The parameters estimated from the GLM for vessel, year and

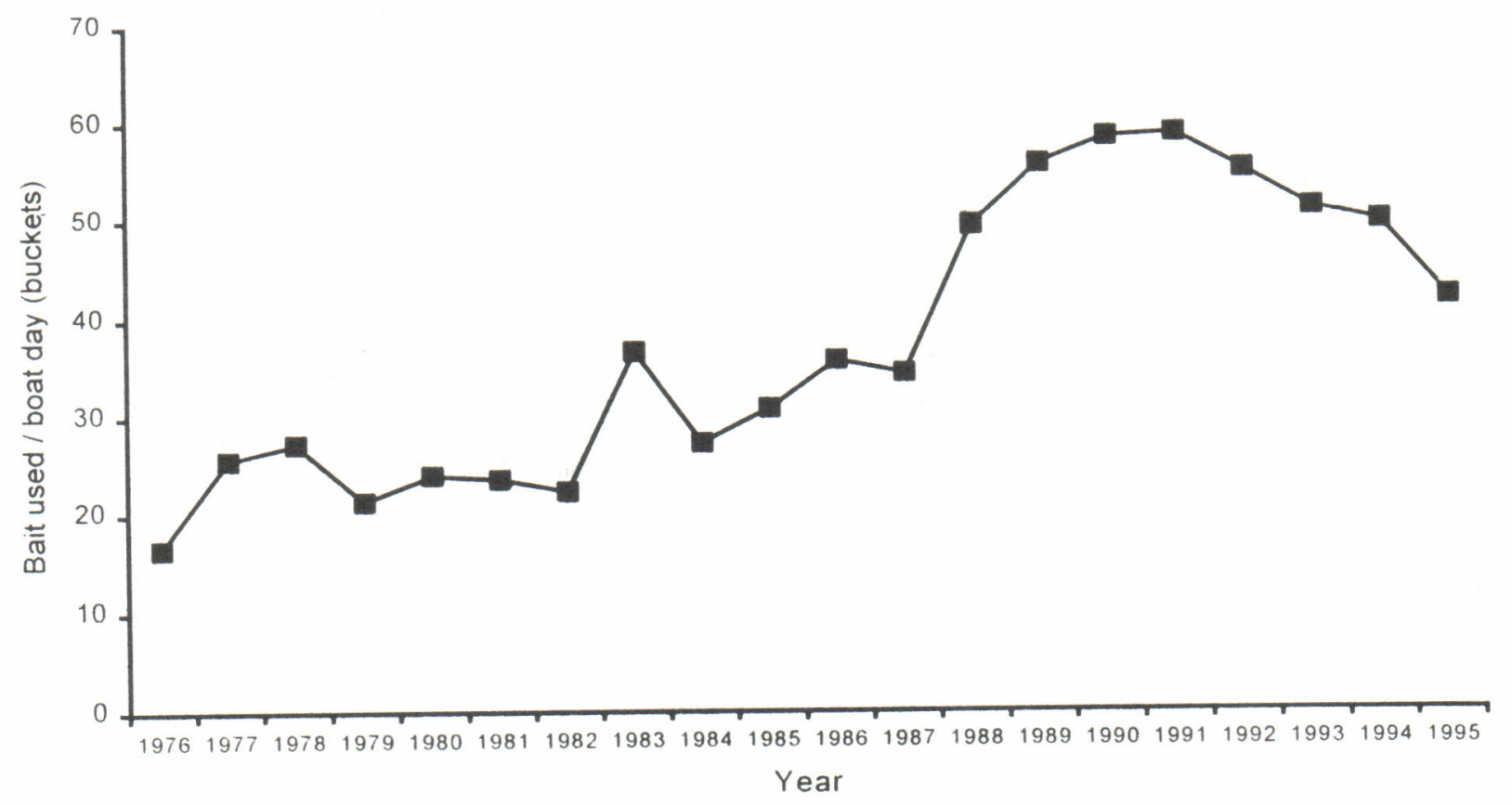

Figure 6. The number of buckets of baitfish used per day per vessel for pole-and-vessels operating from Sorong from 1976 to 1995. 


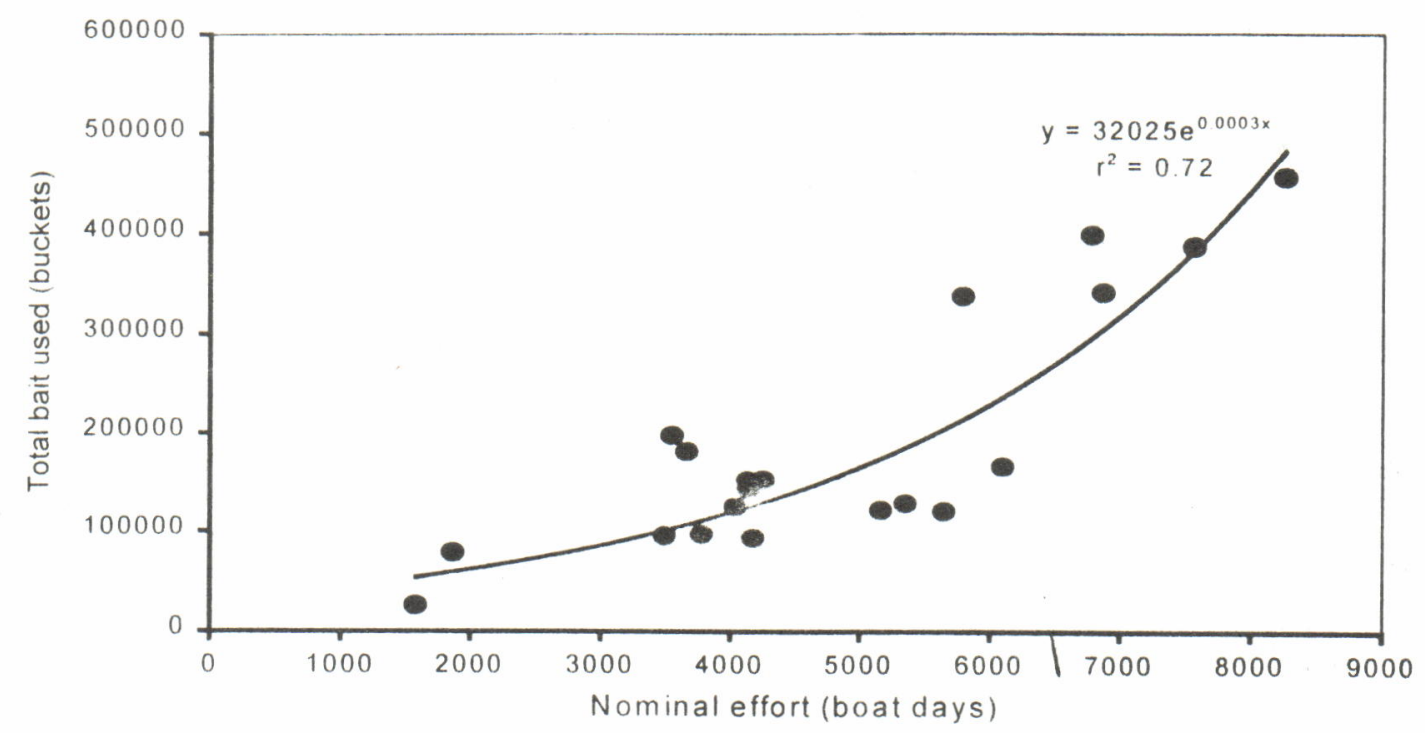

Figure 7. The annual amount of baitfish used by pole-and-line vessels operating from Sorong versus the annual number of uncorrected operational fishing days (nominal effort) by these vessels from 1976 to 1995 .

Table 1. Results for the various models to explain the amount of baitfish used per boat day.

\begin{tabular}{lc}
\hline \multicolumn{1}{c}{ Model } & $\mathbf{r}_{\text {adj }}$ \\
\hline Model 1 Ln(Bait used $)=$ constant + year & 0.490 \\
Model 2 Ln(Bait used $)=$ constant + vessel & 0.388 \\
Model 3 Ln(Bait used $)=$ constant + month & 0.100 \\
Model 4 Ln(Bait used $)=$ constant + year + vessel & 0.549 \\
Model 5 Ln(Bait used $)=$ constant + year + vessel + month & 0.562 \\
\hline
\end{tabular}

month analysis of the bait used per day data are given in Tables 2 and 3 .

There is a linear relationship between corrected annual fishing effort (effective effort) and total baitfish used (Figure 8). Since 1976 to 1995 there has been an average of 34.7 buckets of baitfish used per boat day.

The difference between the annual nominal and effective effort for baitfish is shown in Figure 9. Effective fishing effort for tuna increased by $784 \%$ from the start of the fishery in 1976 to the effort recorded in 1992. Since 1992 there has been a decline in both the nominal and effective fishing effort for baitfish.

\section{Tuna Caught per Day}

There were 6127 monthly records of vessels which had complete estimates of both tuna caught, baitfish used and number of operational fishing days. There has been an increase in the amount of tuna caught per boat day from 1976 to 1991 with a decline after 1991 (Figure 10).

The total bait used by all vessels plotted against the total (uncorrected) number of operational fishing days (nominal fishing effort) shows that there has been an exponential increase in tuna caught per day at the higher levels of fishing effort (see Figure 11). 
Table 2. Parameters estimated from the data for bait used per day for the variables vear and month. Constant for the model was $\log (16.2)=2.783$

\begin{tabular}{cccccc}
\hline Year & Log value & Value & Month & Log value & Value \\
\hline 1977 & 0.307 & 1.359 & January & 0.064 & 1.066 \\
1978 & 0.467 & 1.595 & February & 0.102 & 1.107 \\
1979 & 0.205 & 1.228 & March & 0.120 & 1.127 \\
1980 & 0.208 & 1.323 & April & 0.130 & 1.139 \\
1981 & 0.257 & 1.293 & May & 0.220 & 1.246 \\
1982 & 0.217 & 1.242 & June & 0.158 & 1.171 \\
1983 & 0.761 & 2.140 & July & 0.054 & 1.055 \\
1984 & 0.444 & 1.559 & August & -0.001 & 0.999 \\
1985 & 0.567 & 1.763 & October & 0.060 & 1.062 \\
1986 & 0.661 & 1.937 & November & 0.154 & 1.166 \\
1987 & 0.652 & 1.919 & December & 0.081 & 1.084 \\
1988 & 0.940 & 2.560 & & & \\
1989 & 1.009 & 2.743 & & & \\
1990 & 0.886 & 2.425 & & & \\
1991 & 0.827 & 2.286 & & & \\
1992 & 0.704 & 2.022 & & & \\
1993 & 0.546 & 1.726 & & & \\
1994 & 0.490 & 1.632 & & & \\
1995 & 0.386 & 1.471 & & & \\
\hline
\end{tabular}

\section{Vessel comparisons for tuna caught per boat day}

The progressive improvement in the quantity of the total variation in the amount of tuna caught per boat day is shown in Table 4 . The 'best' model including the variables vessel, year, month and Ln (bait used per boat day) accounted for about $53 \%$ of the variability in the monthly bait used per vessel $(F=62.4$, df $=115, P<0.0001)$. The parameters estimated from the GLM for vessel. vear and month analysis of the bait used per day data are given in Tables 5 and 6 . There is a linear relationship between corrected annual fishing effort (effective effort) and total tuna caught (Figure 12). Since 1976 to 1995 there has been an average of $835 \mathrm{~kg}$ of tuna caught per boat day.

The amount of bait used per boat day was an important factor in explaining the variation in the tuna catch per boat day. The parameter generated by the model for bait per boat day was 0.982 . This suggests that there is an almost linear relationship between tuna caught per boat day and the amount of bait used per boat day (with slowly decreasing ratios of tuna caught to bait used for higher levels of bait used per day). The intercept for the model was 0.031 which equates to $31 \mathrm{~kg}$ of tuna caught for every bucket of baitfish used. As one bucket contains approximately $7 \mathrm{~kg}$ of baitfish (Naamin \& Gafa, this volume), the tuna to baitfish ratio is approximately 4.4 .

The difference between the annual nominal and effective effort for tuna is shown in Figure 13. Effective fishing effort for tuna increased by $820 \%$ from the start of the fishery in 1976 to the effort recorded in 1992. Since 1992 there has been a decline in both the nominal and effective fishing effort for tuna.

\section{DISCUSSION}

Fishing vessel characteristics such as size, tonnage, or speed can impact greatly on catch rates (Hilborn \& Walters 1992). The general linear model (GLM) provides a very powerful, consistent method for examining the effects of vessel differences on trends in tuna and baitfish abundance. However, if catch rate by a specific vessel type in a specific area is not proportional to abundance, then the mean catch rates estimated from GLM will not be proportional to abundance (Hilborn \& Walters 1992). 
Table 3. Parameters estimated from the data for bait used per day for the variable vessels.

\begin{tabular}{|c|c|c|c|c|c|}
\hline Vessel Identity & Log value & Value & Vessel identity & Log value & Value \\
\hline Vessel 1 & 0.569 & 1.766 & Vessel 46 & 0.341 & 1.406 \\
\hline Vessel 2 & 0.573 & 1.774 & Vessel 47 & 0.482 & 1.619 \\
\hline Vessel :3 & 0.034 & 1.035 & Vessel 48 & 0.370 & 1.448 \\
\hline Vessel 4 & 0.556 & 1.744 & Vessel 49 & 0.279 & 1.322 \\
\hline Vessel 5 & 0.516 & 1.675 & Vessel 50 & 0.255 & 1.290 \\
\hline Vessel 6 & 0.878 & 2.406 & Vessel 51 & 0.424 & 1.528 \\
\hline Vessel 7 & 0.339 & 1.404 & Vessel 52 & 0.301 & 1.351 \\
\hline Vessel 8 & 0.444 & 1.559 & Vessel 53 & 0.359 & 1.432 \\
\hline Vessel 9 & 0.061 & 1.063 & Vessel 54 & 0.143 & 1.154 \\
\hline Vessel 10 & -0.121 & 0.886 & Vessel 55 & 0.231 & 1.260 \\
\hline Vessel 11 & -0.114 & 0.892 & Vessel 56 & 0.400 & 1.492 \\
\hline Vessel 12 & -0.010 & 0.990 & Vessel 57 & 0.404 & 1.498 \\
\hline Vessel 13 & -0.110 & 0.896 & Vessel 58 & 0.499 & 1.647 \\
\hline Vessel 14 & -0.125 & 0.882 & Vessel 59 & 0.434 & 1.543 \\
\hline Vessel 15 & 0.137 & 1.147 & Vessel 60 & 0.593 & 1.809 \\
\hline Vessel 16 & -0.132 & 0.876 & Vessel 61 & 0.549 & 1.732 \\
\hline Vessel 17 & -0.206 & 0.814 & Vessel 62 & 0.692 & 1.998 \\
\hline Vessel 18 & 0.018 & 1.018 & Vessel 63 & 0.285 & 1.330 \\
\hline Vessel 19 & -0.221 & 0.802 & Vessel 64 & -0.014 & 0.986 \\
\hline Vessel 20 & -0.143 & 0.867 & Vessel 65 & -0.317 & 0.728 \\
\hline Vessel 21 & -0.080 & 0.923 & Vessel 66 & 0.415 & 1.514 \\
\hline Vessel '22 & -0.021 & 0.979 & Vessel 67 & 0.469 & 1.598 \\
\hline Vessel 2:3 & -0.051 & 0.950 & Vessel 68 & 0.538 & 1.713 \\
\hline Vessel 24 & -0.124 & 0.883 & Vessel 69 & 0.524 & 1.689 \\
\hline Vessel 25 & 0.049 & 1.050 & Vessel 70 & 0.283 & 1.327 \\
\hline Vessel 26 & -0.091 & 0.913 & Vessel 71 & 0.423 & 1.527 \\
\hline Vessel 27 & -0.002 & 0.998 & Vessel 72 & 0.240 & 1.271 \\
\hline Vessel 28 & -0.135 & 0.874 & Vessel 73 & 0.334 & 1.397 \\
\hline Vessel 29 & 0.073 & 1.076 & Vessel 74 & 0.058 & 1.060 \\
\hline Vessel 30 & -0.065 & 0.937 & Vessel 75 & 0.332 & 1.394 \\
\hline Vessel 31 & -0.114 & 0.892 & Vessel 76 & 0.462 & 1.587 \\
\hline Vessel 32 & -0.076 & 0.927 & Vessel 77 & 0.507 & 1.660 \\
\hline Vessel 33 & -0.089 & 0.915 & Vessel 78 & 0.602 & 1.826 \\
\hline Vessel 34 & -0.056 & 0.946 & Vessel 79 & 0.166 & 1.181 \\
\hline Vessel 35 & -0.084 & 0.919 & Vessel 80 & 0.465 & 1.592 \\
\hline Vessel 36 & -0.121 & 0.886 & Vessel 81 & 0.439 & 1.551 \\
\hline Vessel 37 & -0.164 & 0.849 & Vessel 82 & 0.618 & 1.855 \\
\hline Vessel 38 & 0.391 & 1.478 & Vessel 83 & 0.664 & 1.943 \\
\hline Vessel 39 & 0.326 & 1.385 & Vessel 84 & 0.110 & 1.116 \\
\hline Vessel 40 & 0.337 & 1.401 & & & \\
\hline Vessel 41 & 0.292 & 1.339 & & & \\
\hline Vessel 42 & 0.360 & 1.433 & & & \\
\hline Vessel 43 & 0.478 & 1.613 & & & \\
\hline Vessel 44 & 0.391 & 1.478 & & & \\
\hline Vessel 45 & 0.402 & 1.495 & & & 。 \\
\hline
\end{tabular}




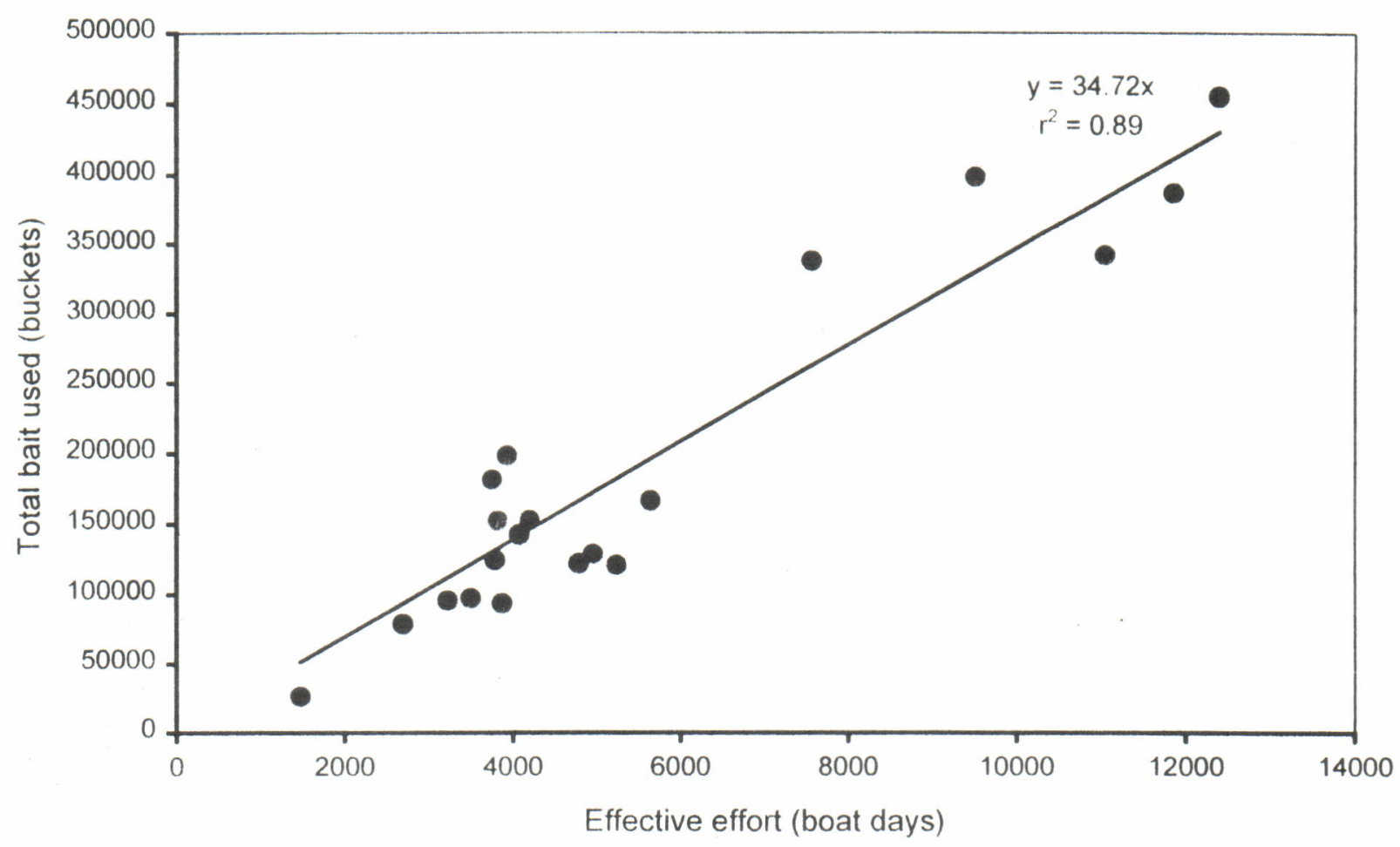

Figure 8. The annual amount of baitfish used by pole-and-line vessels operating from Sorong versus the annual number of corrected operational fishing days (effective effort) by these vessels from 1976 to 1995 .

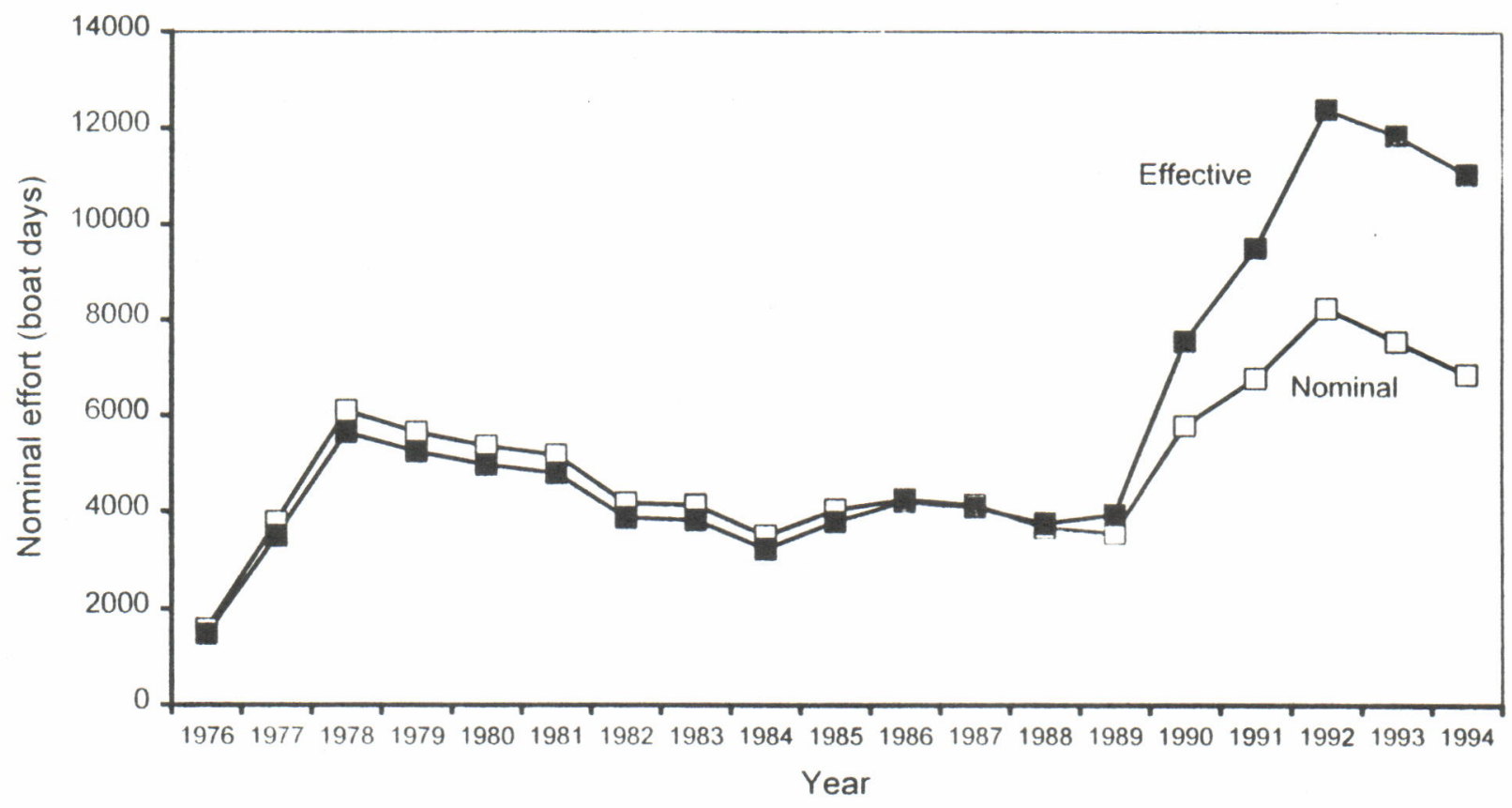

Figure 9. The number of uncorrected operational fishing days (nominal effort) and the number of corrected operational fishing days (effective effort) for baitfish for pole-and-line vessels operating from Sorong from 1976 to 1995. 


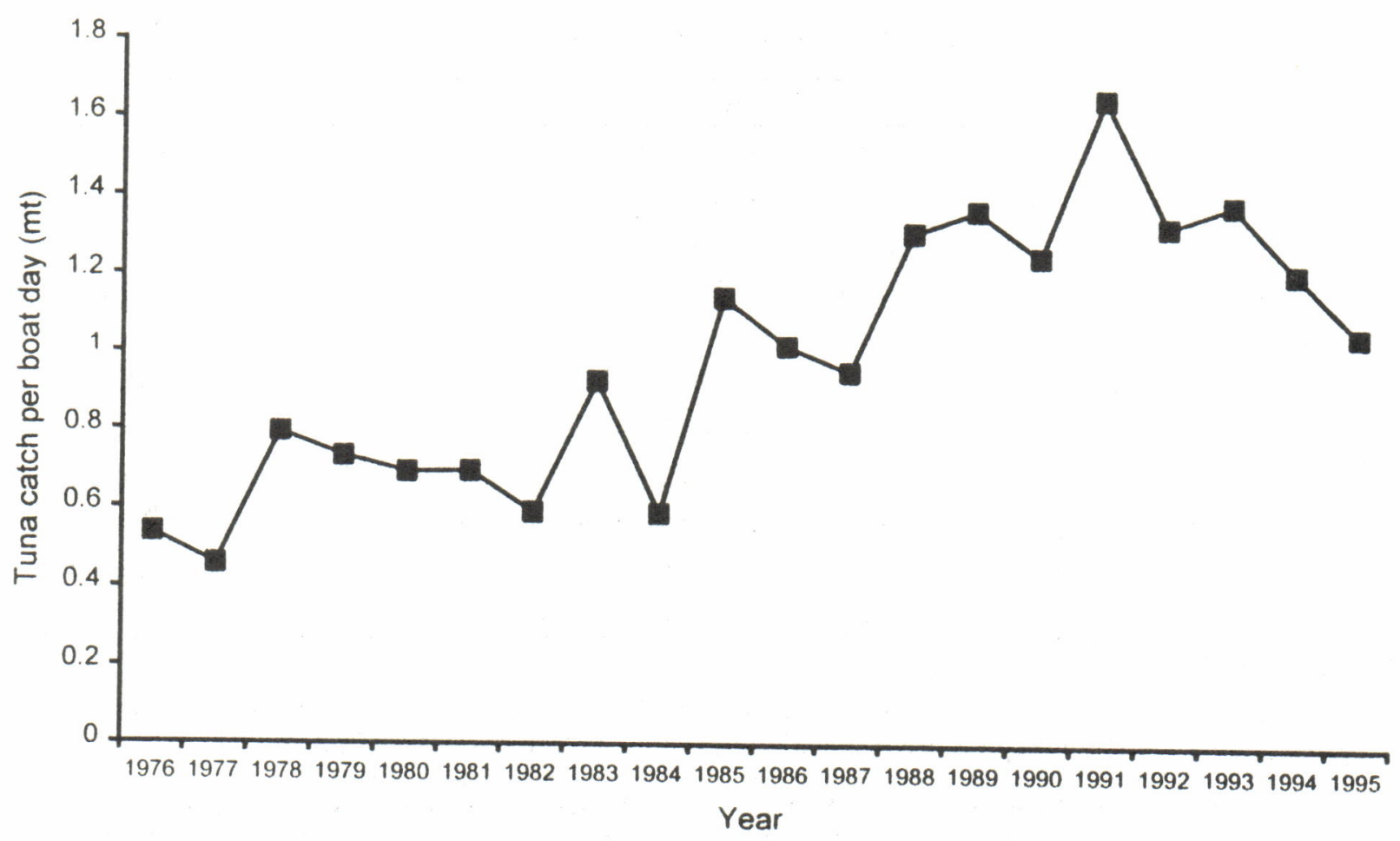
Figure 10. The amount of tuna caught per day per vessel for pole-and-vessels operating from Sorong
from 1976 to 1995 .

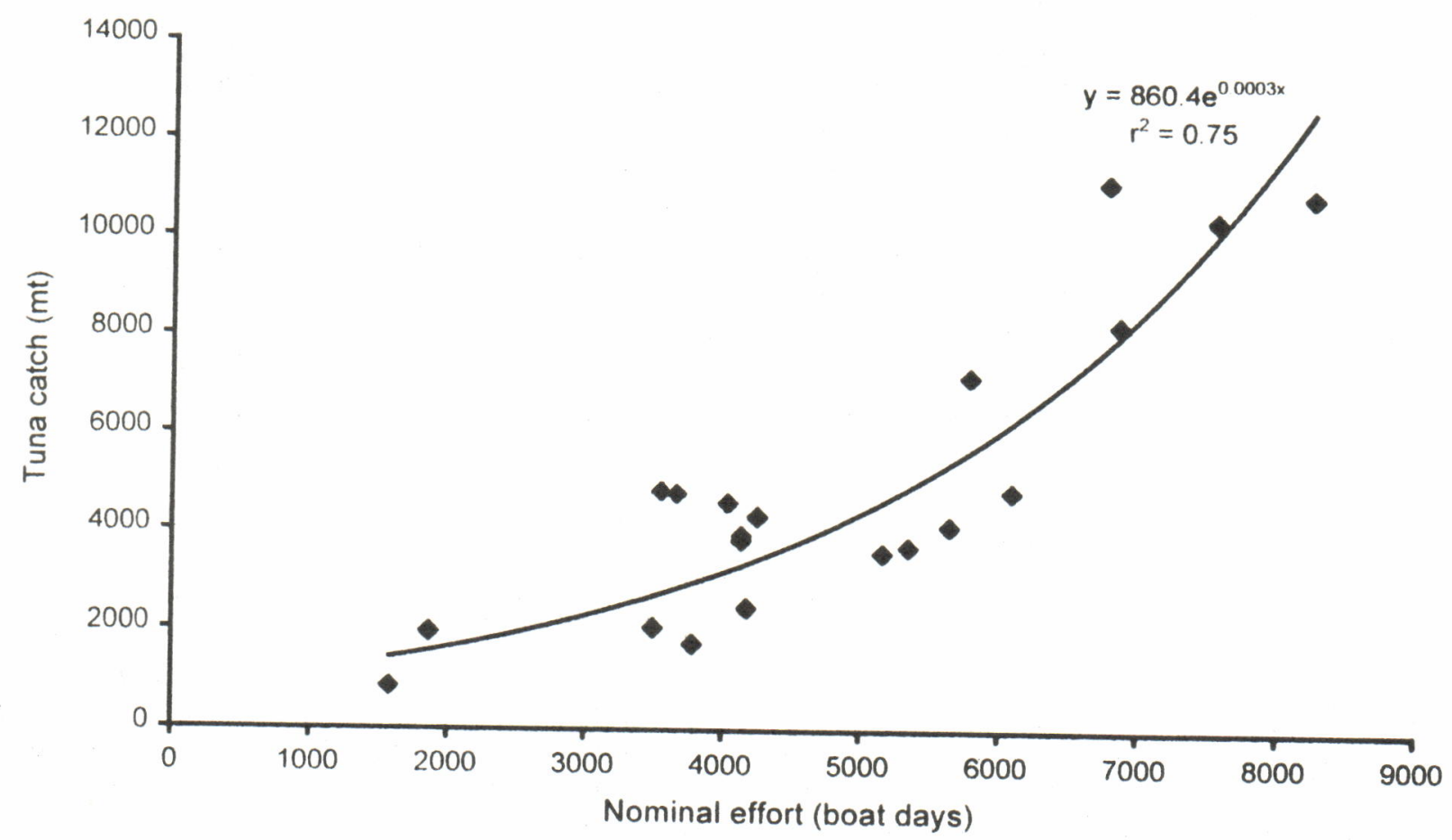

Figure 11. The annual amount of tuna caught by pole-and-line vessels operating from Sorong versus the annual number of uncorrected operational fishing days (nominal effort) by these vessels from 1976 to 1995 . 
Table 4. Results for the model for tuna caught per boat day.

\begin{tabular}{|c|c|}
\hline $\begin{array}{ll} & \text { Model } \\
\end{array}$ & $\mathbf{R}_{\text {adj }}^{2}$ \\
\hline Model 1 Ln('Tuna caught) = constant + year & 0.206 \\
\hline Model 2 Ln('Tuna caught $)=$ constant + vessel & 0.213 \\
\hline Model 3 Ln('Tuna caught $)=$ constant + month & 0.320 \\
\hline Model 4 Ln('Tuna caught) = constant + Ln(bait) & 0.423 \\
\hline Model 5 Ln(Tuna caught $)=$ constant $+\operatorname{Ln}($ bait $)+$ year & 0.472 \\
\hline Model 6 Ln(Tuna caught $)=$ constant + Ln(bait) + vessel & 0.457 \\
\hline Model 7 Ln('Tuna caught $)=$ constant $+\operatorname{Ln}($ bait $)+$ month & 0.445 \\
\hline Model 8 Ln(Tuna caught $)=$ constant $+\operatorname{Ln}($ bait $)+$ year + vessel & 0.514 \\
\hline Model $9 \operatorname{Ln}($ Tuna caught $)=$ constant $+\operatorname{Ln}($ bait $)+$ year + month & 0.494 \\
\hline Model 10 Ln(Tuna caught $)=$ constant + Ln(bait $)+$ vessel + month & 0.480 \\
\hline Model $11 \operatorname{Ln}($ Tuna caught $)=$ constant $+\operatorname{Ln}($ bait $)+$ vessel + year + month & 0.535 \\
\hline
\end{tabular}

Table 5. Parameters estimated from the data for tuna caught per day for the variables year, month and bait per day. Constant for the model was $\log (0.031)=-3.471$

\begin{tabular}{cccccc}
\hline Year & Log value & Value & Month & Log value & Value \\
\hline 1977 & -0.607 & 0.545 & January & -0.297 & 0.743 \\
1978 & -0.046 & 0.955 & February & -0.249 & 0.780 \\
1979 & 0.100 & 1.105 & March & -0.139 & 0.870 \\
1980 & -0.190 & 0.827 & April & -0.032 & 0.969 \\
1981 & -0.058 & 0.944 & May & -0.046 & 0.955 \\
1982 & -0.263 & 0.769 & June & -0.211 & 0.810 \\
1983 & -0.224 & 0.799 & July & -0.236 & 0.790 \\
1984 & -0.378 & 0.685 & August & -0.305 & 0.737 \\
1985 & 0.182 & 1.200 & October & 0.050 & 1.051 \\
1986 & -0.087 & 0.917 & November & -0.013 & 0.987 \\
1987 & -0.145 & 0.865 & December & -0.096 & 0.908 \\
1988 & -0.232 & 0.793 & & & \\
1989 & -0.348 & 0.706 & Bait per day & & \\
1990 & -0.663 & 0.515 & & & \\
1991 & -0.394 & 0.674 & & & \\
1992 & -0.633 & 0.531 & & & \\
1993 & -0.589 & 0.555 & & & \\
1994 & -0.785 & 0.456 & & & \\
1995 & -0.471 & 0.624 & & & \\
\hline
\end{tabular}

There are situations where CPUE do not accurately reflect changes in the abundance of the fish stock. These situations usually relate to the measure of fishing effort that is recorded and the way fishing effort may actually be changing because of increasing efficiency (King 1995).

In Sorong, the measure of fishing effort is the operational fishing day. However over time the vessel characteristics of the fleet have changed and so therefore has the capacity to take baitfish and the catch of tuna per day. This is exactly the situation when CPUE would not accurately reflect changes in abundance of the fish stock.

The estimates of catch rate of baitfish for each pole-and-line vessel based at Sorong is not proportional to fish abundance for the reasons already 
Table 6. Parameters estimated from the data for tuna caught per day for the variable vessel.

\begin{tabular}{|c|c|c|c|c|c|}
\hline Vessel Identity & Log value & Value & Vessel identity & Log value & Value \\
\hline Vessel 1 & 0.577 & 1.781 & Vessel 46 & 0.307 & 1.359 \\
\hline Vessel 2 & 0.689 & 1.992 & Vessel 47 & 0.321 & 1.379 \\
\hline Vessel 3 & 0.295 & 1.343 & Vessel 48 & 0.290 & 1.336 \\
\hline Vessel 4 & 0.445 & 1.560 & Vessel 49 & 0.488 & 1.629 \\
\hline Vessel 5 & 0.480 & 1.616 & Vessel 50 & 0.277 & 1.319 \\
\hline Vessel 6 & 0.679 & 1.972 & Vessel 51 & 0.383 & 1.467 \\
\hline Vessel 7 & 0.442 & 1.556 & Vessel 52 & 0.461 & 1.586 \\
\hline Vessel 8 & 0.615 & 1.850 & Vessel 53 & 0.379 & 1.461 \\
\hline Vessel 9 & -0.020 & 0.980 & Vessel 54 & 0.249 & 1.283 \\
\hline Vessel 10 & 0.288 & 1.334 & Vessel 55 & 0.409 & 1.505 \\
\hline Vessel 11 & -0.103 & 0.902 & Vessel 56 & 0.375 & 1.455 \\
\hline Vessel 12 & -0.034 & 0.967 & Vessel 57 & 0.176 & 1.192 \\
\hline Vessel 13 & -0.079 & 0.924 & Vessel 58 & 0.599 & 1.820 \\
\hline Vessel 14 & 0.096 & 1.101 & Vessel 59 & 0.926 & 2.524 \\
\hline Vessel 15 & -0.165 & 0.848 & Vessel 60 & 0.805 & 2.237 \\
\hline Vessel 16 & -0.118 & 0.889 & Vessel 61 & 0.666 & 1.946 \\
\hline Vessel 17 & -0.188 & 0.829 & Vessel 62 & 0.713 & 2.040 \\
\hline Vessel 18 & -0.115 & 0.891 & Vessel 63 & 0.418 & 1.519 \\
\hline Vessel 19 & -0.152 & 0.859 & Vessel 64 & 0.078 & $1.081^{\circ}$ \\
\hline Vessel 20 & 0.153 & 1.165 & Vessel 65 & -0.721 & 0.486 \\
\hline Vessel 21 & 0.007 & 1.007 & Vessel 66 & 0.787 & 2.197 \\
\hline Vessel 22 & 0.003 & 1.003 & Vessel 67 & 0.502 & 1.652 \\
\hline Vessel $2: 3$ & 0.179 & 1.196 & Vessel 68 & 0.571 & 1.770 \\
\hline Vessel 24 & 0.232 & 1.261 & Vessel 69 & 0.577 & 1.781 \\
\hline Vessel 25 & -0.125 & 0.882 & Vessel 70 & 0.357 & 1.429 \\
\hline Vessel 26 & 0.080 & 1.083 & Vessel 71 & 0.505 & 1.657 \\
\hline Vessel 27 & 0.331 & 1.392 & Vessel 72 & 0.010 & 1.010 \\
\hline Vessel 28 & 0.022 & 1.022 & Vessel 73 & 0.130 & 1.139 \\
\hline Vessel 29 & 0.101 & 1.106 & Vessel 74 & 0.401 & 1.493 \\
\hline Vessel 30 & -0.008 & 0.992 & Vessel 75 & 0.585 & 1.795 \\
\hline Vessel 31 & 0.016 & 1.0) 16 & Vessel 76 & 0.354 & 1.425 \\
\hline Vessel 32 & 0.013 & 1.013 & Vessel 77 & 0.484 & 1.623 \\
\hline Vessel 33 & 0.261 & 1.298 & Vessel 78 & 0.729 & 2.073 \\
\hline Vessel 34 & -0.006 & 0.994 & Vessel 79 & 0.243 & 1.275 \\
\hline Vessel 35 & 0.092 & 1.096 & Vessel 80 & 0.720 & 2.054 \\
\hline Vessel 36 & .0 .007 & 0.993 & Vessel 81 & 0.885 & 2.423 \\
\hline Vessel 37 & 0.045 & 1.046 & Vessel 82 & 0.502 & 1.652 \\
\hline Vessel 38 & 0.109 & 1.115 & Vessel 83 & 0.506 & 1.659 \\
\hline Vessel 39 & 0.299 & 1.349 & Vessel 84 & 0.069 & 1.071 \\
\hline Vessel 40 & 0.234 & 1.264 & & & \\
\hline Vessel 41 & 0.352 & 1.422 & & & 。 \\
\hline Vessel 42 & 0.250 & 1.284 & & & \\
\hline Vessel 43 & 0.068 & 1.070 & & & \\
\hline Vessel 44 & 0.122 & 1.130 & & & \\
\hline Vessel 45 & 0.223 & 1.250 & & & \\
\hline
\end{tabular}




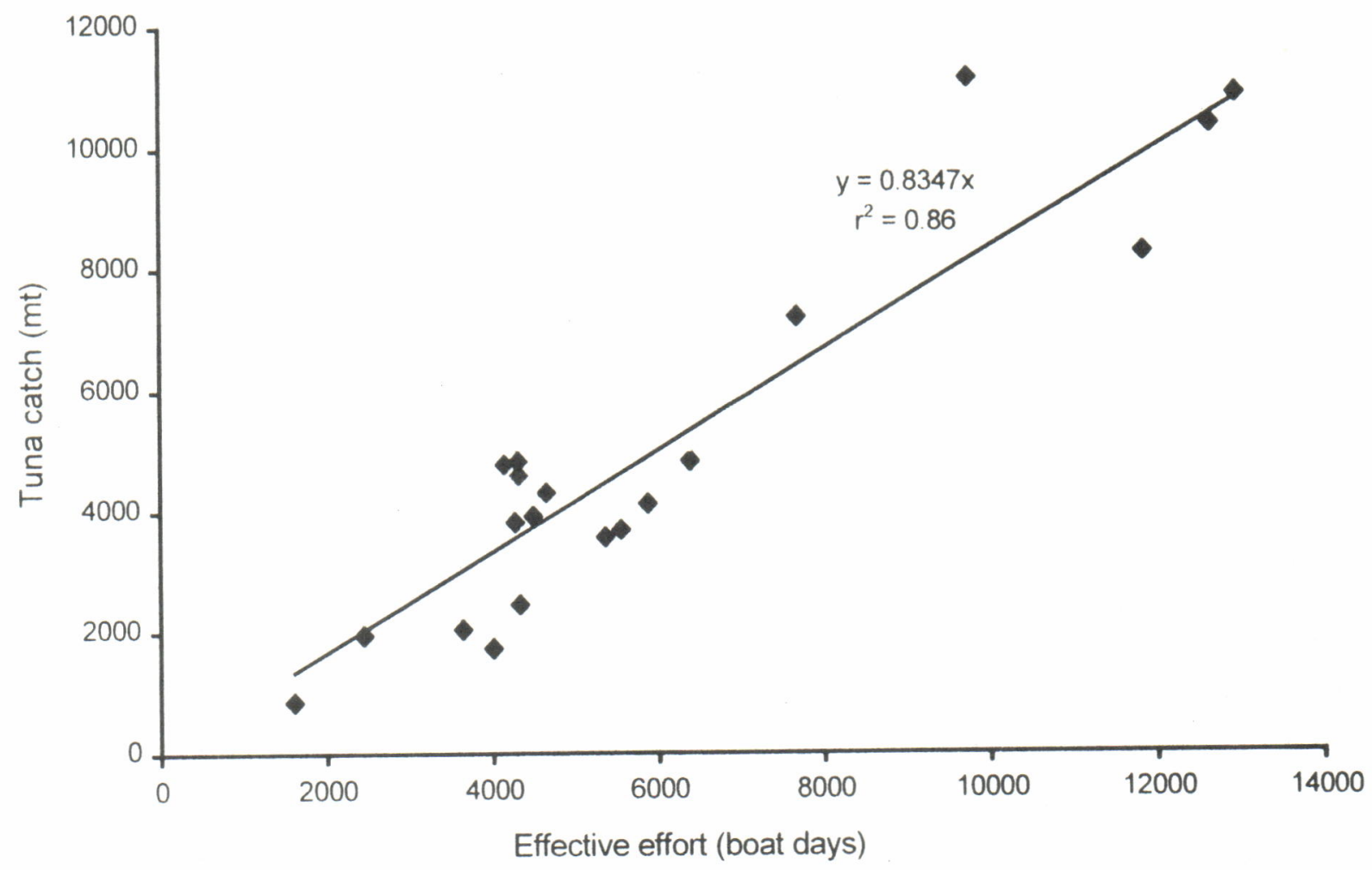

Figure 12. The annual amount of tuna caught by pole-and-line vessels operating from Sorong versus the annual number of corrected operational fishing days (effective effort) by these vessels from 1976 to 1995 .

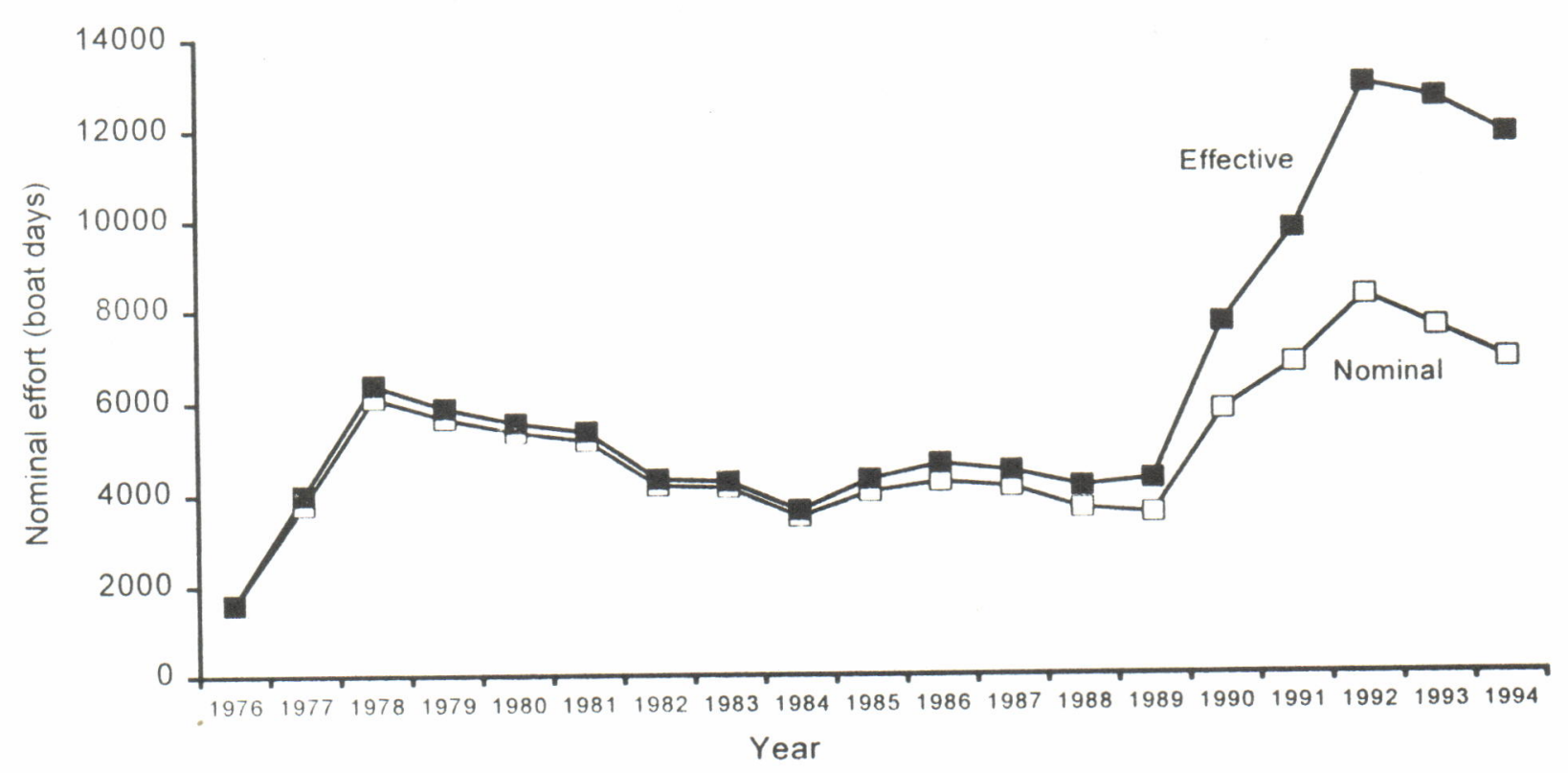

Figure 13. The number of uncorrected operational fishing days (nominal effort) and the number of corrected operational fishing days (effective effort) for tuna for pole-and-line vessels operating from Sorong from 1976 to 1995. 
stated. Therefore, the GLM can only provide us with differences in the use of bait between poleand-line vessels. However, this is important in order to understand the changes in demand for baitfish by the pole-and-line fleet and standardising fishing effort over time.

The results show that the increased demand for baitfish over time is primarily due to the larger size classes of vessel that are entering the poleand-line fleet based at Sorong. However there must be a concern that the amount of bait used by each pole-and-line vessel reached a maximum in 1991 and since then has been declining. The amount of baitfish used per fishing day by each individual pole-and-line vessel will be influenced by:

(a) The capacity of the live-bait tanks on the poleand-line vessel - the larger the vessel the larger the bait tank capacity and therefore the greater the demand for baitfish by the pole-and-line vessel. In most circumstances the pole-and-line vessel captain will try to maximise the amount of baitfish that is carried before steaming to the tuna fishing grounds.

(b) Availability of baitfish to the pole-and-line vessels which will be dependent on:

(i) the abundance of baitfish at any particular time, and

(ii) the amount of baitfish supplied by the bagans. This will be influenced by the number of bagans that are operating and the demand for baitfish by other users of the resources e.g. dried salted fish. If it becomes unprofitable to supply baitfish to the pole-and-line fleet, bagan operators will either stop working or look for better prices fot the baitfish. If this situation occurs, then the pole-and-line vessels will not be able to take their maximum requirement of baitfish. In this situation, low usage of baitfish will not be an indication of low abundance of baitfish but the inability of the bagan operators to meet the demand for baitfish by the pole-and-line fleet.
Therefore the decline in bait used per boat day since 1991 could be attributable to a decline in abundance of the baitfish but could also be to due a reduced capacity of the bagans to supply the baitfish. There may even have been a conscious decision by pole-and-skippers to reduce the amount of baitfish they carry as higher stocking densities within the bait tanks may have increased the mortality of baitfish while steaming to the tuna fishing grounds. Any of these options or combina. tion of options could be a possible reason for the decline in the amount of baitfish taken per day. Only with more detailed information would it possible to make the correct conclusions.

From the analysis of the tuna caught per day it is apparent that there is a strong link between baitfish used per day and the amount of tuna caught per day. The declining a mount of bait used per day since 1991 has led to reduced catch rates of tuna per day from 1.64 tonnes per day in 1991 to 1.05 tonnes per day in 1995 .

This trend must be a concern for Usaha Mina and pole-and-line vessels working in the fishery. It is important that the reasons for these trends are identified as soon as possible. Without accurate catch and effort data recorded from each of the baitfishing locations it is impossible to detect whether there is a declining abundance of baitfish at any of the baitgrounds commonly used by the pole-and-line fleet.

It is therefore imperative that accurate records of actual catch of tuna and baitfish are kept. These records must include baitfish used for human consumption, baitfish that die in the bagans before being transferred to the pole-and-line vessels and actual baitfishing (hauls of the bagan net) are recorded from each location that supplies baitfish. Only then will it be possible to assess the abundance of baitfish based on fishery-dependent data. Without accurate catch and effort data, the abundance of baitfish at each baitground can only be assessed by fisheries independent techniques such as the egg production method (Milton et al., this volume). These techniques can only provide an estimate of baitfish abundance at the time of sampling and will not show trends over time unless the sampling is conducted on a regular basis. 


\section{REFERENCES}

Kimura, D.K. 1981. Standardised measures of relative abundance based on modelling log (c.p.u.e.). and their application to Pacific ocean perch (Srbastes alutus). J. du Conssil Inter. pour l'Exploration de la Mer 39: 211-218.

King, M. 1995. Fisheries Biology, Assessment and Man. agement. Fishing News Books.

Hilborn, R. and Walters, C.J. 1992. Quantitative Fish. eries Stock Assessment - Choice Dynamics and Un. rertainty. Chapman and Hall.
Milton, D.A.. Andamari, R. and Rawlinson, N.J.F. 1999. The biomass of tropical anchovies (Encrasicholina species) at Bacan, eastern Indonesia estimated by the daily egg production method. Indon. Fish. Res. J. (This volume).

Naamin. N. and Gafa, B. 1999. Tuna baitfish and the pole-and-line fishery in eastern Indonesia - an overview. Indon. Fish. Res. J. (This volume).

Rawlings, J.O., Pantula, S.G. and Dickey, D.A. 1998. Applied Regression Analysis: A Research Tool - $2^{\text {nd }}$ edition. Springer-Verlag New York Inc. 